\title{
Diversity of NTFPs and Their Utilization in Adilabad District of Andhra Pradesh, India
}

\author{
Kanneboyena Omkar \\ Plantation Manager, Andhra Pradesh Forest Development Corporation Limited \\ Thaadbund, Medak Division, Andhra Pradesh 500 009, India \\ Tel: 91-984-941-6082Ｅ-mail: omkarbot@gmail.com \\ Sateesh Suthari \\ Plant Systematics Laboratory, Department of Botany, Kakatiya University \\ Warangal, Andhra Pradesh 506 009, India \\ Tel: 91-944-171-2719 E-mail: suthari.botany@gmail.com
}

Samata Alluri

1908 Continental Ave Apt 309, Naperville, Illinois 60563, USA

Tel: 1-612-423-4484Ｅ-mail: samatareddyalluri@gmail.com

Ajmeera Ragan

Plant Systematics Laboratory, Department of Botany, Kakatiya University

Warangal, Andhra Pradesh 506 009, India

Tel: 91-984-946-2614 E-mail: raganajmeera@yahoo.co.in

Vatsavaya S. Raju (Corresponding author)

Plant Systematics Laboratory, Department of Botany, Kakatiya University

Warangal, Andhra Pradesh 506 009, India

Tel: 91-984-941-3063 E-mail: rajuvatsavaya@gmail.com

Received: October 14, 2011

Accepted: December 2, $2011 \quad$ Published: March 1, 2012

doi:10.5539/jps.v1n1p33

URL: http://dx.doi.org/10.5539/jps.v1n1p33

\begin{abstract}
Adilabad in Andhra Pradesh is a backward district, with 37.72\% of geographic area under forest cover and inhabited by $17.08 \%$ ethnic people who use the local tropical dry deciduous forests to extract Non-Timber Forest Products (NTFPs) for self-consumption and economic subsistence. The analysis of NTFPs in six forest divisions of Adilabad district, viz. Adilabad, Bellampalli, Jannaram, Kagaznagar, Mancherial and Nirmal reveals the use of consumptive category of goods like wild food plants, honey, oils, fodder, etc. on one hand and the non-consumptive items like gums, resins, gum-resins, dyes, wax, lac, fibers, fuel wood, charcoal, fencing material, brooms, wildlife products, raw materials like bamboo and cane for handicrafts, etc. besides the medicinal plants. The NTFP diversity shows the cognitive ability of the people while the products extracted belong to 183 flowering plant species which represent 149 genera of 64 families (164 Magnoliopsida; 19 Liliopsida). The Legumes dominate the list with 31 taxa, followed by Rubiaceae (11) and Euphorbiaceae (7). Most of the NTFP species are phanerophytes (61\% trees) and indigenous. The government of Andhra Pradesh has a procurement policy and price index for select NTFPs by which the stakeholders get reasonable seasonal
\end{abstract}


income through the collection and sale of beedi leaf, gums (karaya, thiruman, konda gogu), stem bark (narra mamidi), fleshy corolla (ippa), fruits (karakkaya, kunkudu), seeds (chilla, mushti, morli), etc.

Keywords: India, Adilabad, NTFP diversity, Rural economy

\section{Introduction}

Forest is a natural ecosystem constituting an important, non-renewable living resource. Forest ecosystems of the world make up the Forest Biome, a vital terrestrial biomass producer and repository of biological diversity. Forests have the potential for improving human well-being through supplementing income while functioning as safety nets (Angelsen \& Wunder, 2003). Since forests play an important role in the sustainability of life on land, humans rightly resorted to reserve one third of the natural terrestrial plant cover. In view of the global forest decline, the UN has named 2011 as the 'International Year of Forests' in the 'Decade for Biodiversity'. Therefore, there is a need to study the local forests from the standpoints of nature and extent of their resource utilization.

India is the seventh largest country in the world though it owns $1.8 \%$ of the global forests on the $2.5 \%$ of the global land area. To serve Gross Domestic Product (GDP) as a measure of nation's wealth, not as mere measure of economic growth, India has initiated green accounting (Gundimeda et al., 2007). Three parameters are used to value the environmental resource wealth, namely (i) Timber, non-timber forest products (NTFPs) and carbon, (ii) Biodiversity, and (iii) Ecological services. With changing political economy of forest resources around the world, the benefits of NTFPs are increasingly discussed in valuing tropical forests (Tewari, 2000). In this regard, the diversity of NTFPs and their role in the sustenance of local people constitutes a prime concern.

All biological materials that are found in the forests, excluding the timber, are called NTFPs. These include consumptive category of goods like wild food plants, spices, honey, oils, fodder, etc. on one hand and the non-consumptive items like gums, resins, gum-resins, dyes, wax, lac, brooms, fibers, fuel wood, charcoal, fencing, wildlife products, raw materials like bamboo, cane, etc. The forests in India, once known for their valuable timbers, are now looked at for their NTFPs, with a clear shift in the paradigm. The rural people (largely the scheduled tribe category) inhabiting the forests areas carry a very long history of extraction of NTFPs, for subsistence and/or sale. NTFPs have been identified as one of key income sources for rural households, with live examples indicating an income share greater than that from cash crops or informal cash incomes (Dovie, 2003).

Forest is a living resource while extraction of its produce is a dynamic aspect, with spatial and temporal implications. Forest management policies are increasingly spatial while making the forest land towards resource protection (reserves, sanctuaries, parks, etc.) and extraction (buffer zones), recreation (ecotourism) opportunities, etc. (Robinson et al., 2008). Since NTFPs constitute the only natural resource that provides free access and subsistence to the poorest of the poor, they should really assume greater importance and receive priority for their development and management. In this regard, there is a need to document the NTFP diversity and availability for utilization per habitat. The present study aims at providing a glimpse of NTFP diversity and how it is utilized in the forests of Adilabad district of Andhra Pradesh, India.

\section{Study Area}

\subsection{Biophysical environment}

Adilabad district is located between longitudes $77^{\circ} 47^{\prime}$ and $80^{\circ} 0^{\prime} \mathrm{E}$ and latitudes $18^{\circ} 40^{\prime}$ and $19^{\circ} 56^{\prime} \mathrm{N}$. It has a long boundary with Maharashtra (north by Yeotmal and Chanda districts, on the east Chanda district, on the west Nanded district) and on the south by Karimnagar and Nizamabad districts of Andhra Pradesh. The district occupies the second position in the State in regard to the area under forests. The ethnic population of the district is $17.08 \%$, with prominent indigenous tribal groups such as Gonds, Kolams, Naikpods, Pardhans, Koyas, Mannewars, Andhs, Thoties and Yerukalas (Anonymous, 2011). Of the ethnic people, Gonds constitute the dominant group $(52.16 \%)$. Geographically, these people are responsible for the name Gondwanaland, the southern of the two super continents believed to have constituted super continent 'the Pangea'. The study site enjoys typical tropical climate with four seasons, with average rainfall of $742 \mathrm{~mm}$ and temperature varying from $28-41^{0} \mathrm{C}$ in the hot season (Anonymous, 1975).

\subsection{Socio-economic environment}

Although these forests provide multiple benefits and cover $21 \%$ of the geographical area, this sector contributes only $1.5 \%$ to the official GDP in India. Andhra Pradesh has $63,821 \mathrm{sq} \mathrm{km}$ of area under forests (unreserved 50,479 , protected 12,365 and unclassified $977 \mathrm{sq} \mathrm{km}$ ). It is equal to $23.2 \%$ of the geographic area of the State as per Forest Survey of India Report (FSI, 2009). When it is to be maintained at 33\%, the actual forest cover is $16.1 \%$, spread in $44,419 \mathrm{sq} \mathrm{km}$ with $62.7 \mathrm{~m}^{3} /$ ha growth stock (volume). The GDP contribution to the national 
account by the state of Andhra Pradesh is 17,902 through timber and 1,063.2 million rupees by NTFPs (Gundimeda et al., 2007). Adilabad is a backward district with greater area under forests (6084 sq km, i.e. $37.72 \%$ of geographic area - FSI, 2009) and $16.54 \%$ ethnic people when the state average is $6.59 \%$. The Kolams, Mannewars and Thoties in the district are the most backward and poorest of the ethnic people. They are classified as Primitive Tribal Group (PTG), to draw special attention (Rao, 1993). The economic empowerment of tribal women in Adilabad district, using the NTFPs, was discussed by Omkar et al. (2008).

\section{Methodology}

The present study has taken up NTFP analysis in six forest divisions of Adilabad district, viz. Adilabad, Bellampalli, Jannaram, Kagaznagar, Mancherial and Nirmal. The study included all the majority tribal villages with natural forests around where the ethnic people subsist on NTFP products. Ethnobotanical survey was conducted for two years and the economic survey for one year. The study has to draw both primary and secondary sources of data. The primary data (Tables 1 and 2) were collected through field surveys and interacting with people (stakeholders) in person (interviews), questionnaires, household surveys and vegetation studies whilst the secondary data (Tables 3 and 4) were gathered from Girijan Co-operative Corporation (GCC), District forest working plans, reports, etc.

\section{Results}

\subsection{NTFP diversity}

The diversity of available NTFP species and their products in the natural forests were studied in Adilabad district during the years 2008-2010. In the study area, there are 183 species of Magnoliophyta (Angiosperms) which provide minor forest produce. These species are arranged alphabetically under the respective families and genera with the local (vernacular) names (Telugu), followed by scientific (botanical) name and use/s (Table 1). The NTFPs belong to 149 genera representing 64 families (Dicots/Magnoliopsida - 164 and Monocots/Liliopsida 19). As regards the growth forms, trees predominate $(111 ; 60.66 \%)$, followed by shrubs $(29 ; 15.85 \%)$, herbs $(21$; $11.48 \%)$, climbers $(19 ; 10.37 \%)$ and lianas/stragglers $(3 ; 1.64 \%)$, indicating that the floral elements are primarily woody (trees, phanerophytic) and are from the forest. Furthermore, these species are predominantly $(89.07 \%)$ indigenous and the rest (10.93\%) cultivated/planted/naturalized.

The predominance of the tree species $(61 \%)$ in the study area indicates the fact that they all construct the tropical dry deciduous forest ecosystem and provide goods and render other ecosystem services to the local people at no costs.

\subsection{The use of NTFPS}

The various NTFP-yielding species found in the Adilabad district forests, as per the consumptive and non-consumptive use-categories, are:

\subsubsection{Consumptive (Edible)}

\subsubsection{Fruits}

Maredu (Aegle marmelos), Morli (Buchanania lanzan), Tumiki (Diospyros melanoxylon), Velaga (Limonia acidissima), Nalla jeedi (Semicarpus anacardium), Mamidi (Mangifera indica), Naguru (Radermachera xylocarpa), Garugu (Garuga pinnata), Banka nakkiri (Cordia dichotoma), Illintha (Diospyros chloroxylon), Tella alli (Maba buxifolia), Korra maddi (Bridelia retusa), Narra mamidi (Litsea glutinosa), Dudippa (Careya arborea), Bikki (Gardenia gummifera), Alli (Memecylon edule), Tada (Grewia tiliifolia), Pusuku (Schleichera oleosa), Adavi draksha (Cissus vitiginea), Neredu (Syzygium cumini), Pedda bikki (Gardenia latifolia) and Chilla (fruit pulp of Strychnos potatorum) besides those of the exotics planted: *Chinta (Tamarindus indica), *Jeedi mamidi (Anacardium occidentale), *Thati (Borassus flabellifer), *Regu (Ziziphus mauritiana), *Chinthaphal kaya (Annona squamosa), *Rama phal (Annona reticulata), etc.

\subsubsection{Tubers/Rhizomes/Roots}

Pilli teegalu (Asparagus racemosus), Pamu donda (Corallocarpus epigaeus), Kevu kanda (Cheilocostus speciosus), Nela thadi (Curculigo orchioides), Tella nelathadi (Chlorophytum arundinaceum), Bellam gadda (Dioscorea alata), Chenna gadda (Dioscorea bulbifera) and Govinda gadda (Dioscorea pentaphylla).

\subsubsection{Other parts}

Tender/young leaves (vegetable): Konda pindi - Aerva lanata, Alli - Memecylon edule; Fleshy corolla: Ippa (Madhuca indica); Seed kernel: Pedda morli (Buchanania axillaris), Chinna morli (Buchanania lanzan); Seeds: 
Bojja (Xylia xylocarpa); Seed oil: Ippa (Madhuca indica), Pusuku (Schleichera oleosa) and purgative *Amudam (Ricinus communis).

\subsubsection{Non-Consumptive}

\subsubsection{Leaves}

Beedi (for smoking) - Diospyros melanoxylon, Adda leaves (meal plates) - Bauhinia vahlii, Mothuku - Butea monosperma, Teega mothuku - Butea superba and Barrenka - Streblus asper. Of these, beedi leaf brings good income to the local people during the season in view of procurement policy and established procedure for its trade in the study area or elsewhere in the district (Table 2). The income from beedi leaf gathering is reasonably good for the people who incur no expenses in the workout.

\subsubsection{Gums, resins and gum-resins}

Tapsi (Kavalama urens), Thiruman (Anogeissus latifolia), Gumpena (Lannea coromandelica), Peddegi (Pterocarpus marsupium), Somi (Soymida febrifuga), Konda gogu (Cocholospermum religiosum), Tella tumma (Acacia leucophloea), Dirisena (Albizia lebbeck), Jammi (Prosopis cineraria), Velaga (Limonia acidissima), Erra buruga (Bombax ceiba), Chinduga (Albizia odoratissima), and gum-resin Anduku (Boswellia serrata), Bikki (Gardenia gummifera), Pedda bikki (Gardenia latifolia) and Chinna karinga (Gardenia resinifera).

\subsubsection{Barks}

Rela (Cassia fistula), Narra mamidi (Litsea glutinosa), Nalla maddi (Terminalia alata), Tangedu (Senna auriculata), etc.

\subsubsection{Fibre}

Yepi (Hardwickia binata), Nul thada (Helicteres isora), Aare (Bauhinia racemosa), Nara botku (Eriolaena hookeriana), etc.

\subsubsection{Bamboo}

Mulla veduru (Bambusa arundinacea), Veduru (Dendrocalamus strictus). The district has 12,214 ha (1.37\%) area under bamboo, with an annual yield of 700 tons, of $35 \%$ which is used for pulp and $20 \%$ for rural consumption.

\subsubsection{Brooms}

Konda cheepuru (Thysanolaena maxima), Thatching grass (Imperata cylindrica), Chiluka parre (Sida acuta), bulrush (Typha species), Eatha (Phoenix sylvestris), etc.

\subsubsection{Toys}

Pala (Wrightia tinctoria), Tella poliki (Givotia moluccana) and Kummari poliki (Gyrocarpus americanus).

4.2.3 Medicinal (Ethno-human medicine; Ethnoveterinary)

Roots/rhizomes- Nabhi (Gloriosa superba), whole plant or leaf - Nimma gaddi (Cymbopogon flexuosus), Adavi munaga (Moringa concanensis), Maredu (Aegle marmelos), Gara (Balanites roxburghii), Mushti (Strychnos nux-vomica), Tanikkaya (Terminalia bellirica), Karakkaya (Terminalia chebula), Usiri (Phyllanthus emblica), Nela vemu (Andrographis paniculata) and Poda patri (Gymnema sylvestre). The opportunity for gathering and sale of medicinal plants from the district is immense since Swamy (2009) recorded as many as 366 taxa which are used in 1378 ethnomedicinal practices. The global sales of non-timber based herbal medicine were around US $\$ 30$ billion in 2000; this market is growing roughly at the rate of $15 \%$ per annum (Anonymous, 2002).

\subsection{The procurement and sale of NTFPS}

The main players who market the NTFPs in the district are Girijan Co-operative Corporation (GCC), Andhra Pradesh Forest Department (APFD) and the private traders. The GCC trades with 17 notified NTFPs (Table 3) and it also purchases non-notified Garugu (Garuga pinnata), Karakkaya (Terminalia chebula) and Lakka/Lac (Schleichera oleosa) (Omkar, 2011). APFD deals with the collection of beedi leaf (Diospyros melanoxylon) while its trade is made by Andhra Pradesh Forest Development Corporation (APFDC). The private traders are involved in the trade with 15 of the notified NTFPs, namely Adda leaf (Bauhinia vahlii), kernel of Sarapappu (Buchanania lanzan), gum-resinof Karinga (Gardenia gummifera), gum of Tapsi (Kavalama urens), seeds (Nalla jeedi - Semicarpus anacardium; Visha mushti - Strychnos nux-vomica; Kanuga - Pongamia pinnata; Ippa Madhuca indica), stem bark of Narra mamidi (Litsea glutinosa), fruits of Vaalugapalla chettu (Acacia sinuata), *Kunkudu (Sapindus trifoliatus), Chinta (Tamarindus indica), Usiri (Phyllanthus emblica) and Karakkaya (Terminalia bellirica), and hill broom (Thysanolaena maxima). 


\section{Discussion and Conclusions}

About 70 million ethnic people all over the globe primarily depend on forests for their livelihood. NTFPs play a vital role in the economic subsistence of ethnic people who depend on the forest ecosystems. Currently, the tropical forested areas and their biodiversity are subjected to over exploitation and degradation due to heavy extraction and grazing livestock pressures. Despite the fact that 50 million people in India over the past 150 years obtained part of their livelihood from forests, the nation's forest policy continued to focus primarily on the commercial aspects. However, the New Forest Policy 1988 had envisaged the need and means for involving forest-dependent communities as partners in the management of the forest resources. Local people (Gonds and Naikpods) managing local forests in Behroonguda (Jannaram Forest Division) of Adilabad district (D'Silva and Nagnath, 1999) showed the way in Andhra Pradesh through Vana Samrakshana Samithis (VSSs) and Joint Forest Management (JFM) initiatives. The income (gain) from nine NTFPs in the year 1998 for their own consumption and sale was estimated to be $₹ 144,959$ with 347 people involved in the hamlet.

The Dry deciduous forests in India were estimated to have more economic value than had been assumed previously, and it is compared favourably against the potential timber revenue (Mahapatra \& Tewari, 2005). The present study endorses this observation.

Through the initiative of Government of Andhra Pradesh, the people of Kanchanbari and Pedumpet were involved in basket making with bamboo, a group of women from Pavarguda VSS located in Jainoor Mandal extract biodiesel from Pongamia seeds while the local villagers from Pittabangaram VSS in Indravalli Mandal are party to the collection and processing of Lac with the help of the Velugu Project and Andhra Pradesh Forest Department (TERI, 2004). It is estimated that the household income for the ethnic people of Adilabad (TERI, 2004) comes largely from labour (51\%), followed by agriculture (35\%) and NTFPs $(15 \%)$; the last-mentioned does not include self-consumption.

Of the NTFPs available, the procurement of Gum karaya has been important for the revenue in Adilabad district. The procurement data of Gum karaya for the district by GCC Limited at Utnoor are available for seven consecutive years, i.e. from 2001-2002 to 2008-2009 (Table 4). The data indicate that the procurement of the Gum karaya was on the average of six quintals per year. The procurement was highest in 2004-05 when the production reached $968.34 \mathrm{~kg}$, providing an all time record income of $₹ 74.92$ lakhs. The quantity of gum produced has gone down to the minimum $(192.79 \mathrm{~kg})$ during the year 2008-09 with an income of about 15 lakhs, which is less than the $1 / 3$ of the average procurement for the study area and lowest in recent times.

Next in importance is beedi leaf gathering in the district. The income generation data were gathered for six villages in the study area (Table 2). The income through it was highest per household per season (₹ 2201) for Bombaiguda and lowest ( $₹$ 1575) for Peddabanda, whilst the average was $₹ 1818$.

There is an increasing focus on the potential role of forests and NTFPs in the economic development and poverty reduction strategies (Shackleton et al., 2007). The present study finds that there is: (i) a great diversity of NTFPs in the district though they are gathered from a fairly uniform and preponderant teak forest ecosystem; (ii) NTFP diversity in the district helped the ethnic people to exploit the forest resource for livelihood by self-employment; they gather the forest produce (because of kinds and their seasonal availability) throughout the year, under no preoccupation; (iii) keeping in view the forest community aspect, the procurement policy of forest produce by Government of Andhra Pradesh was based on the principle to ensure the buying of the select forest products through local purchase points. The gums (karaya, thiruman and konda gogu), seeds (visha mushti, chilla, Pongamia, chinta), roots (sarpagandhi) and leaves (tumiki) provide the bulk of the income; and (iv) A considerable proportion of the poor households use NTFPs for self-consumption than their wealthier counterparts in the district, thereby saving part of the expenditure on these items.

In the poverty alleviation schemes of the ethnic people, the policy and practices of the Government of Andhra Pradesh and Andhra Pradesh Forest Development Corporation Limited must include and conceive the diversity of NTFPs on one hand and the cognitive ability of the ethnic people on the other, for mutual benefits. Central to these twin objectives shall be the sustainable use of NTFPs.

\section{Acknowledgements}

Dr K. Omkar is thankful the Andhra Pradesh Forest Department, India in general and in particular Mr A. Kishan (DFO) of Jannaram Division, Mr R. Laxman Rao, Mr Tiryani and Mr Ravinder of Bellampally Division and Mr Rajasekhar of Kaghaznagar Divison of Adilabad district, for their help and encouragement during the field work while Sateesh Suthari is grateful to Dr V.K. Dadhwal and Dr Sarnam Singh, IIRS, Dehra Dun for financial 
assistance through Vegetation Carbon Pool Project. The authors thank the Head, Department of Botany, Kakatiya University, Warangal, for facilities.

\section{References}

Angelsen, A., \& Wunder, S. (2003). Exploring the Forest-Poverty Link: Key, Concepts, Issues and Research Implications. CIFOR Occasional Paper 40. Center for International Forestry Research, Bogor, Indonesia.

Anonymous. (1975). Gazetteer of Adilabad District. Government of Andhra Pradesh, Government Press, Hyderabad.

Anonymous. (2002). International Trade. Forum, 4, 11-12.

Anonymous. (2011). Census Report. Government of Andhra Pradesh, Hyderabad.

Dovie, D.B.K. (2003). Rural economy and livelihoods from the non-timber forest products trade. Compromising sustainability in southern Africa? International Journal of Sustainable Development and World Ecology, 10, 247-262. http://dx.doi.org/10.1080/13504500309469803

D'Silva, E., \& Nagnath, B. (1999). Local people managing local forests: Behroonguda shows the way in Andhra Pradesh, India. Asia Forest Network Working Paper Series No.3. Asia Forest Network, Santa Barbara, USA.

Gundimeda, H., Sukhdev, P., Sinha, R.K., \& Sanyal, S. (2007). Natural resource accounting for Indian states illustrating the case of forest resources. Ecological Economics, 61, 635-649. http://dx.doi.org/10.1016/j.ecolecon.2006.07.035

FSI. (2009). State of Forest Report. Forest Survey of India, Dehra Dun.

Mahapatra, A.K., \& Tewari, D.D. (2005). Importance of non-timber forest products in the economic valuation of dry deciduous forests of India. Forest Policy and Economics, 7, 455-467. http://dx.doi.org/10.1016/j.forpol.2004.02.002

Omkar, K. (2011). Non-Timber Forest Products - their Diversity and Availability, and the Economic Subsistence of the Rural people in Adilabad District of Andhra Pradesh. Ph.D. Thesis, Kakatiya University, Warangal.

Omkar, K., Ragan, A., \& Raju, V.S. (2008). Economic empowerment of tribal women of Adilabad district of Andhra Pradesh, utilizing non-timber forest products. pp. 96-98. In: Proc. Nation. Seminar on "Globalization-Agricultural Development of Tribes, Issues and Challenges". Kakatiya University, Warangal, Andhra Pradesh.

Rao, K.M. (1993). Socio-cultural Profile of Tribes of Andhra Pradesh. Tribal Cultural Research and Training Institute, Hyderabad.

Robinson, E.J.Z., Albers, H.J., \& Williams, J.C. (2008). Spatial and temporal modeling of community non-timber forest extraction. Journal of Environmental Economics and Management, 56, 234-245. http://dx.doi.org/10.1016/j.jeem.2008.04.002

Shackleton, C.M., Shackleton, S.E., Buiten, E., \& Bird, N. (2007). The importance of dry forests and woodlands in rural livelihoods and poverty alleviation in South Africa. Forest Policy \& Economics, 9, 558-577. http://dx.doi.org/10.1016/j.forpol.2006.03.004

Swamy, N.S. (2009). Ethnobotanical Knowledge from Adilabad district, Andhra Pradesh, India. Ph.D. thesis, Andhra University, Waltair, Visakhapatnam.

TERI. (2004). Sustainable Exploitation, Cultivation and Marketing Linkages of Non-Timber Forest Products (NTFPs) in Andhra Pradesh. The Energy and Resources Institute, New Delhi. 154 pp. [TERI Project Report No. 2003 SF 63]

Tewari, D.D. (2000). Managing non-timber forest products as an economic resource. Journal of Interdisciplinary Economics, 11, 269-287.

\section{Note}

Note. *exotics 
Table 1. NTFP species and their use category

\begin{tabular}{|c|c|c|}
\hline & Family/Local Name/Scientific Name & Use \\
\hline & Alangiaceae & \\
\hline \multirow[t]{2}{*}{1} & Oodugu - Alangium salvifolium (L.f.) Wang. & $\begin{array}{l}\text { Bark used as purgative, for skin diseases; fruits } \\
\text { laxative, refrigerant. }\end{array}$ \\
\hline & Anacardiaceae & \\
\hline 2 & Jeedi mamidi - *Anacardium occidentale L. & $\begin{array}{l}\text { Pseudocarp edible, pericarp yields oil; seed kernal } \\
\text { edible. }\end{array}$ \\
\hline 3 & $\begin{array}{l}\text { Pedda morli - Buchanania axillaris (Desr.) } \\
\text { Ramamoorthy }\end{array}$ & Seed kernel edible; used in the preparation of sweets. \\
\hline 4 & $\begin{array}{l}\text { Chinna morli, Sarapappu - Buchanania lanzan } \\
\text { Spreng. }\end{array}$ & Seed kernal edible. \\
\hline 5 & $\begin{array}{l}\text { Dumpena, Oddi - Lannea coromandelica } \\
\text { (Houtt.) Merr. }\end{array}$ & Bark used to heal wounds. \\
\hline 6 & Mamidi - Mangifera indica L. & Fruit edible. \\
\hline \multirow[t]{2}{*}{7} & Nalla jeedi - Semecarpus anacardium L. & $\begin{array}{l}\text { Pseudocarp edible; fruit juice used as marker } \\
\text { (marking nut); medicinal. }\end{array}$ \\
\hline & Annonaceae & \\
\hline 8 & Chinthaphal kaya - *Annona squamosa L. & $\begin{array}{l}\text { Fruit edible; seed powder used as insecticides; root } \\
\text { purgative. }\end{array}$ \\
\hline 9 & Rama phal - *Annona reticulata $\mathrm{L}$. & Fruit edible. \\
\hline 10 & $\begin{array}{l}\text { Barre duddi, Chiluka dudduga - Miliusa } \\
\text { tomentosa (Roxb.) Sinclair }\end{array}$ & $\begin{array}{l}\text { Bark powder a veterinary medicine; wood used for } \\
\text { building huts. }\end{array}$ \\
\hline \multirow[t]{2}{*}{11} & $\begin{array}{l}\text { Gutti duddugu - Polyalthia cerasoides (Roxb.) } \\
\text { Bedd. }\end{array}$ & Fodder; wood used for houseposts and carpentary. \\
\hline & Amaranthaceae & \\
\hline 12 & Uttareni - Achyranthes aspera L. & Tender leaves edible; roots used as tooth brush. \\
\hline 13 & Pindi kura - Aerva lanata (L.) Juss. & Leafy vegetable; kidney stones. \\
\hline 14 & $\begin{array}{l}\text { Ponnaganti kura - Alternanthera sessilis (L.) } \\
\text { R.Br. ex DC. }\end{array}$ & Leafy vegetable. \\
\hline \multirow[t]{2}{*}{15} & Gunugu - Celosia argentea L. & Leafy vegetable. \\
\hline & Apiaceae & \\
\hline \multirow[t]{2}{*}{16} & Bokkudu - Centella asiatica (L.) Urban & Leaves hair tonic; brain tonic. \\
\hline & Apocynaceae & \\
\hline 17 & Kalimi - Carissa spinarum L. & Young fruits edible, made curry or chetney. \\
\hline 18 & $\begin{array}{l}\text { Kodisa pala, Tedla pala - Holarrhena } \\
\text { pubescens (Buch.-Ham.) Wall. ex Don }\end{array}$ & $\begin{array}{l}\text { Stem and root bark used in dysentery; wood useful in } \\
\text { carving toys; floss used for stuffing pillows. }\end{array}$ \\
\hline 19 & Pala - Wrightia arborea (Dennst.) Mabb. & Flowers used as ornamental. \\
\hline 20 & Pala - Wrightia tinctoria $\mathrm{R} . \mathrm{Br}$. & Flowers used as vegetable; leaves source of blue dye. \\
\hline \multirow[t]{2}{*}{21} & $\begin{array}{l}\text { Sarpagandhi - Rauvolfia serpentina (L.) Benth. } \\
\text { ex Kurz }\end{array}$ & Ethnomedicinal, snakebite. \\
\hline & Aristolochiaceae & \\
\hline \multirow[t]{2}{*}{22} & Nalleswari - Aristolochia indica L. & Roots extract antidote for snakebite. \\
\hline & Asclepiadaceae & \\
\hline 23 & Poda patri - Gymnema sylvestre (Retz.) R.Br. & Leaves anti-diabetic. \\
\hline 24 & $\begin{array}{l}\text { Sugandha pala - Hemidesmus indicus (L.) } \\
\text { R.Br. }\end{array}$ & Dried root powder used to cure diarrhoea. \\
\hline \multirow[t]{2}{*}{25} & $\begin{array}{l}\text { Barre sugandha pala }-H \text {. indicus var. } \\
\text { pubescens (Wight \& Arn.) Hook.f. }\end{array}$ & Ethnoveterinary: galactogogue. \\
\hline & Asteraceae & \\
\hline \multirow[t]{2}{*}{26} & Dogorolisi - Pentanema indicum (L.) Ling & Scorpion sting. \\
\hline & Balanitaceae & \\
\hline \multirow[t]{2}{*}{27} & Gara - Balanites roxburghii Planch. & Magico-religious use; fruits fish poison, antidiabetic. \\
\hline & Bignoniaceae & \\
\hline 28 & $\begin{array}{l}\text { Oddi - Dolichandrone falcata (Wall. ex DC.) } \\
\text { Seem. }\end{array}$ & Bark used as fish poison. \\
\hline
\end{tabular}




\begin{tabular}{|c|c|c|}
\hline 29 & $\begin{array}{l}\text { Dundilam - Oroxylum indicum (L.) Benth. ex } \\
\text { Kurz }\end{array}$ & $\begin{array}{l}\text { Seeds purgative; bark used for tanning, dyeing; } \\
\text { medicinal. }\end{array}$ \\
\hline 30 & $\begin{array}{l}\text { Naguru - Radermachera xylocarpa (Roxb.) } \\
\text { Schum. }\end{array}$ & Young fruits edible; bark antisceptic. \\
\hline \multirow[t]{2}{*}{31} & $\begin{array}{l}\text { Kala goru - Stereospermum suaveolens } \\
\text { (Roxb.) DC. }\end{array}$ & Leaves fodder; wood used for making charcoal. \\
\hline & Bixaceae & \\
\hline \multirow[t]{2}{*}{32} & Tabra kaya, Jaffra, Annato - *Bixa orellana L. & $\begin{array}{l}\text { Dye extracted from seed coat, used for colouring } \\
\text { food stuffs. }\end{array}$ \\
\hline & Bombacaceae & \\
\hline 33 & Enugu thondamu - *Adansonia digitata $\mathrm{L}$. & Fruits edible. \\
\hline 34 & Erra buruga - Bombax ceiba L. & $\begin{array}{l}\text { Gum used as medicine; wood light, used for making } \\
\text { plywood, boxes, match sticks, etc. }\end{array}$ \\
\hline \multirow[t]{2}{*}{35} & Buruga - *Ceiba pentandra (L.) Gaertn. & Fibre/cotton from fruit used to stult pillows. \\
\hline & Burseraceae & \\
\hline 36 & Andugu - Boswellia serrata Roxb. & $\begin{array}{l}\text { Bark yields gum-resin, used in treating skin diseases, } \\
\text { rheumatism. }\end{array}$ \\
\hline \multirow[t]{2}{*}{37} & Garugu - Garuga pinnata Roxb. & Fruits pickled; gum medicinal. \\
\hline & Caesalpiniaceae & \\
\hline 38 & Are - Bauhinia racemosa Lam. & $\begin{array}{l}\text { Bark yields good fibre; wood used for fuel; bark } \\
\text { astringent in dysentery. }\end{array}$ \\
\hline 39 & Addaku - Bauhinia vahlii Wight \& Arn. & Leaf plate making. \\
\hline 40 & riegata $\mathrm{L}$. & $\begin{array}{l}\text { Fodder tree, bark yields fibre, used in tanning and } \\
\text { dying. }\end{array}$ \\
\hline 41 & Rela - Cassia fistula L. & Pulp of ripen fruit a strong purgative. \\
\hline 42 & Gatchikayi - Caesalpinia bonduc (L.) Roxb. & $\begin{array}{l}\text { Used as live fence; seeds medicinal, used to play } \\
\text { games. }\end{array}$ \\
\hline 43 & Narepa - Hardwickia binata Roxb. & Bark yields fibre; fodder tree. \\
\hline 44 & Chinta - *Tamarindus indica $\mathrm{L}$. & $\begin{array}{l}\text { Ripen fruits used as refrigerant, digestive, } \\
\text { carminative and laxative; young leaves eaten, fried. }\end{array}$ \\
\hline \multirow[t]{2}{*}{45} & Tangedu - Senna auriculata L. & Tannins extracted. \\
\hline & Capparaceae & \\
\hline 46 & Aadonda - Capparis aphylla Roth & Bark anthelmintic, used as aphrodisiac. \\
\hline 47 & Nalla uppi - Capparis grandis L. & Bark used for healing wounds. \\
\hline 48 & Aadonda-Capparis zeylanica L. & Unripe fruits as vegetable; pickled. \\
\hline \multirow[t]{2}{*}{49} & Vulimiri chettu - Crateva magna (Lour.) DC. & Tender leaves chewed to cure tooth-ache. \\
\hline & Celastraceae & \\
\hline 50 & $\begin{array}{l}\text { Neridi, Butankus - Cassine glauca (Rottb.) } \\
\text { Kuntze }\end{array}$ & $\begin{array}{l}\text { Leaf powder used for headaches; bark decoction } \\
\text { administered for cholera. }\end{array}$ \\
\hline \multirow[t]{2}{*}{51} & $\begin{array}{l}\text { Dantha - Maytenus emarginata (Ruiz \& Pav.) } \\
\text { Loes. }\end{array}$ & Leaf paste used to cure ulcers and sores. \\
\hline & Cochlospermaceae & \\
\hline \multirow[t]{2}{*}{52} & $\begin{array}{l}\text { Konda gogu - Cochlospermum religiosum (L.) } \\
\text { Alston }\end{array}$ & $\begin{array}{l}\text { Bark yields 'Katara' gum, used for cough and } \\
\text { gonorrhoea. }\end{array}$ \\
\hline & Combretaceae & \\
\hline 53 & $\begin{array}{l}\text { Thiruman - Anogeissus latifolia (Roxb. ex } \\
\text { DC.) Wall. ex Guill \& Perr. }\end{array}$ & Fodder, timber useful in making charcoal, fuel. \\
\hline 54 & Bontha-Calycapteris floribunda Lam. & Leaves purgative; baskets made with shoots. \\
\hline 55 & Nalla maddi - Terminalia alata Heyne ex Roth & Bark yields tannin, used as purgative and adhesive. \\
\hline 56 & $\begin{array}{l}\text { Tella maddi - Terminalia arjuna (Roxb. ex } \\
\text { DC.) Wight \& Arn. }\end{array}$ & Bark acrid; febrifuge and diuretic. \\
\hline 57 & $\begin{array}{l}\text { Tanikaya - Terminalia bellirica (Gaertn.) } \\
\text { Roxb. }\end{array}$ & $\begin{array}{l}\text { Fruits important constituent of ayurvedic drugs } \\
\text { (i.e.Triphala churna; for asthma, bronchitis); fruits } \\
\text { also used for dyeing. }\end{array}$ \\
\hline 58 & Karakkaya - Terminalia chebula Retz. & $\begin{array}{l}\text { Fruits important source of tannin; dye; used in } \\
\text { Triphala churna. }\end{array}$ \\
\hline 59 & Are teega - Combretum albidum G.Don & Pegs used to tie cattle; shoots woven into basket. \\
\hline
\end{tabular}




\begin{tabular}{|c|c|c|}
\hline & Cordiaceae & \\
\hline 60 & $\begin{array}{l}\text { Botuku, Banka nakkiri - Cordia dichotoma } \\
\text { Forst.f. }\end{array}$ & Fruits edible, bark astringent; leaves used as fodder. \\
\hline \multirow[t]{2}{*}{61} & Pedda iriki, Iriki - Cordia wallichii G. Don & Fruits edible, pickled. \\
\hline & Cucurbitaceae & \\
\hline 62 & $\begin{array}{l}\text { Pamu donda - Corallocarpus epigaeus (Rottl. } \\
\text { \& Willd.) C.B.Clarke }\end{array}$ & Tubers used for snakebite. \\
\hline \multirow[t]{2}{*}{63} & Aagudu -Trichosanthes tricuspidata Lour. & $\begin{array}{l}\text { Ethnoveterinary: root decoction for dysentery in } \\
\text { cattle. }\end{array}$ \\
\hline & Ebenaceae & \\
\hline 64 & Illintha - Diospyros chloroxylon Roxb. & Fruits edible; wood used as fuel; fodder tree. \\
\hline 65 & Tumiki - Diospyros melanoxylon Roxb. & $\begin{array}{l}\text { Leaves used in making beedis; leaves diuretic, } \\
\text { carminative, laxative; astringent, bark decoction used } \\
\text { in diarrhoea; fruits edible; wood good for fuel. }\end{array}$ \\
\hline 66 & Muchi tumiki - Diospyros montana Roxb. & $\begin{array}{l}\text { Fruit bitter; wood used to make agricultural } \\
\text { implements; fuel wood. }\end{array}$ \\
\hline \multirow[t]{2}{*}{67} & Tella alli - Maba buxifolia (Rottb.) Pers. & Wood used for rafters; fruits edible. \\
\hline & Erythroxylaceae & \\
\hline \multirow[t]{2}{*}{68} & Deva daru - Erythroxylon monogynum Roxb. & Leaves diaphoretic, diuretic. \\
\hline & Euphorbiaceae & \\
\hline 69 & Korra maddi - Bridelia retusa (L.) Spreng. & Fruits edible; bark used in tanning. \\
\hline 70 & $\begin{array}{l}\text { Nalla kodisha - Cleistanthus collinus (Roxb.) } \\
\text { Hook.f. }\end{array}$ & Fruit/bark crushed and mixed in water to stupify fish. \\
\hline 71 & Tella poliki - Givotia moluccana (L.) Sreem. & $\begin{array}{l}\text { Wood soft, used for carving images, toys; seed yields } \\
\text { oil. }\end{array}$ \\
\hline 72 & Adavi nepalamu - *Jatropha curcas L. & $\begin{array}{l}\text { Seeds yield oil, used as bio-diesel; seeds } \\
\text { anthelmintic; leaf juice useful to relieve pains from } \\
\text { piles, inflammation. }\end{array}$ \\
\hline 73 & $\begin{array}{l}\text { Kunkuma - Mallotus philippensis (Lam.) } \\
\text { Muell.-Arg. }\end{array}$ & $\begin{array}{l}\text { Red dye 'kamala' obtained from fruits, used as } \\
\text { kumkum; fruits bitter, anthelmintic, fodder tree. }\end{array}$ \\
\hline 74 & Usiri - Phyllanthus emblica L. & Fruits edible, pickled, medicinal. \\
\hline \multirow[t]{2}{*}{75} & Amudamu - *Ricinus communis L. & Seed oil lubricant; purgative. \\
\hline & Flindersiaceae & \\
\hline \multirow[t]{2}{*}{76} & Bilugu - Chloroxylon swietenia DC. & $\begin{array}{l}\text { Wood hard, valuable in agricultural implements, } \\
\text { serves as good fuel. }\end{array}$ \\
\hline & Hernandiaceae & \\
\hline \multirow[t]{2}{*}{77} & $\begin{array}{l}\text { Kummari poliki - Gyrocarpus americanus } \\
\text { Jacq. }\end{array}$ & $\begin{array}{l}\text { Wood soft, used for carving images, toys; seed yields } \\
\text { oil. }\end{array}$ \\
\hline & Hypoxidaceae & \\
\hline \multirow[t]{2}{*}{78} & Nela thadi - Curculigo orchioides Gaertn. & Roots aphrodisiac; good food for wild pigs. \\
\hline & Lauraceae & \\
\hline \multirow[t]{2}{*}{79} & $\begin{array}{l}\text { Narra mamidi - Litsea glutinosa (Lour.) C.B. } \\
\text { Robinson }\end{array}$ & $\begin{array}{l}\text { Leaves emotient and antispasmodic; fruit edible; root } \\
\text { bitter, astringent, tonic; bark demulcent, astringent, } \\
\text { used to set bone fractures. }\end{array}$ \\
\hline & Lecythidaceae & \\
\hline 80 & $\begin{array}{l}\text { Dudippa, Budda dharmi - Careya arborea } \\
\text { Roxb. }\end{array}$ & $\begin{array}{l}\text { A good coppicer, bark yields fibre; wood hard, used } \\
\text { in agriculutural implements; leaves used in beedi } \\
\text { making; fruits edible; seeds poisonous. }\end{array}$ \\
\hline \multirow[t]{2}{*}{81} & $\begin{array}{l}\text { Batta kanapa - Barringtonia acutangula (L.) } \\
\text { Gaertn. }\end{array}$ & $\begin{array}{l}\text { Wood soft, used for furniture; bark used for } \\
\text { fish-poisoning. }\end{array}$ \\
\hline & Loganiaceae & \\
\hline 82 & Visha mushti - Strychnos nux-vomica L. & $\begin{array}{l}\text { Strychnine, brucine obtained from the seeds; fodder } \\
\text { tree; wood largely used to make agricultural } \\
\text { implements. }\end{array}$ \\
\hline \multirow[t]{2}{*}{83} & Chilla - Strychnos potatorum L. & $\begin{array}{l}\text { Fruit pulp edible; wood hard, durable; good for } \\
\text { agricultural implements. }\end{array}$ \\
\hline & Lythraceae & \\
\hline
\end{tabular}




\begin{tabular}{|c|c|c|}
\hline 84 & Chennangi - Lagerstroemia parviflora Roxb. & $\begin{array}{l}\text { Wood used as timber, fencing, agricultural } \\
\text { implements. }\end{array}$ \\
\hline 85 & Maidaku chettu - *Lawsonia inermis $\mathrm{L}$. & $\begin{array}{l}\text { Leaves paste used for dyeing hands, finger nails and } \\
\text { feet. }\end{array}$ \\
\hline \multirow[t]{2}{*}{86} & Jaaji - Woodfordia fruticosa (L.) Kurz & Dried flowers powder used to cure diarrhoea. \\
\hline & Malvaceae & \\
\hline 87 & Thuthuru benda - Abutilon indicum (L.) Sweet & Tender branches used as tooth brush. \\
\hline 88 & $\begin{array}{l}\text { Ganga raavi - *Thespesia populnea (L.) } \\
\text { Soland. }\end{array}$ & Ornamental. \\
\hline \multirow[t]{2}{*}{89} & $\begin{array}{l}\text { Konda patti - Thespesia lampas (Cav.) Dalzell } \\
\text { \& A.Gibson }\end{array}$ & Yields good fibre. \\
\hline & Melastomataceae & \\
\hline \multirow[t]{2}{*}{90} & Alli - Memecylon edule Roxb. & Fruits edible; wood makes excellent charcoal. \\
\hline & Meliaceae & \\
\hline 91 & Vepa - *Azadirachta indica Juss. & $\begin{array}{l}\text { Ripe fruits yield oil used in parasitic skin diseases; } \\
\text { leaves used to cure chicken pox; wood yields good } \\
\text { timber. }\end{array}$ \\
\hline \multirow[t]{2}{*}{92} & Somi - Soymida febrifuga (Roxb.) Juss. & Bark yields gum; wood hard. \\
\hline & Menispermaceae & \\
\hline 93 & $\begin{array}{l}\text { Farid-butti, Dusara teega - Cocculus hirsutus } \\
\text { (L.) Diels }\end{array}$ & Baskets. \\
\hline 94 & $\begin{array}{l}\text { Bankka teega - Cissampelos pareira L. var. } \\
\text { hirsuta (Buch.-Ham. ex DC.) Forman }\end{array}$ & Root extract administered for stomach/chest pains. \\
\hline \multirow[t]{2}{*}{95} & $\begin{array}{l}\text { Tippa teega - Tinospora cordifolia (Willd.) } \\
\text { Miers ex Hook.f. \& Thoms. }\end{array}$ & Aerial root paste applied on insect stings. \\
\hline & Mimosaceae & \\
\hline 96 & $\begin{array}{l}\text { Sandra - Acacia chundra (Roxb. ex Rottl.) } \\
\text { Willd. }\end{array}$ & Stem bark used to cure skin diseases. \\
\hline 97 & $\begin{array}{l}\text { Tella thumma - Acacia leucophloea (Roxb.) } \\
\text { Willd. }\end{array}$ & $\begin{array}{l}\text { Tree yields gum; used in indigenous medicine; bark } \\
\text { yields fibre. }\end{array}$ \\
\hline 98 & $\begin{array}{l}\text { Nalla tumma }-* \text { Acacia nilotica }(\text { L.) Willd. ex } \\
\text { Del. }\end{array}$ & Fruits eaten by sheep and goats; trunk yields gum. \\
\hline 99 & $\begin{array}{l}\text { Vaalugapalla chettu - Acacia sinuata (Lour.) } \\
\text { Merr. }\end{array}$ & Tender leaves used as vegetable. \\
\hline 100 & Narlinga - Albizia amara (Roxb.) Boiv. & $\begin{array}{l}\text { Fodder tree; flowers useful in skin treatment; useful } \\
\text { for afforestation. }\end{array}$ \\
\hline 101 & Dirisena - *Albizia lebbeck (L.) Benth. & $\begin{array}{l}\text { Fodder tree; bark exudes gum, substitute for Gum } \\
\text { Arabic. }\end{array}$ \\
\hline 102 & Chinduga - Albizia odoratissima (L.f.) Benth. & Fodder tree; bark yields gum, dye. \\
\hline 103 & $\begin{array}{l}\text { Choppari, Tella chinduga - Albizia procera } \\
\text { (Roxb.) Benth. }\end{array}$ & $\begin{array}{l}\text { Bark decoction used in rheumatism and } \\
\text { haemorrhage, also used as fish poison. }\end{array}$ \\
\hline 104 & $\begin{array}{l}\text { Veluthuru - Dichrostachys cinerea (L.)Wight } \\
\& \text { Arn. }\end{array}$ & Wood used as fuel. \\
\hline 105 & Jammi - Prosopis cineraria (L.) Druce & $\begin{array}{l}\text { Fodder tree; pods as feed for cattle and goats; bark } \\
\text { yields gum; shoots used in ceremonials. }\end{array}$ \\
\hline \multirow[t]{2}{*}{106} & Bojja - Xylia xylocarpa (Roxb.) Taub. & Seeds edible. \\
\hline & Moraceae & \\
\hline 107 & Panasa - *Artocarpus heterophyllum Lam. & Fruit edible. \\
\hline 108 & Marri - Ficus benghalensis L. & $\begin{array}{l}\text { Fruit eaten by birds, animals; fodder tree; one of the } \\
\text { host for lac insects. }\end{array}$ \\
\hline 109 & Bomma medi - Ficus hispida L.f. & $\begin{array}{l}\text { Fruit used in curries; ripe fruits edible; fodder tree; } \\
\text { bark yields fibre. }\end{array}$ \\
\hline 110 & Raavi - Ficus religiosa L. & Fruits eaten by animals, birds, fodder tree. \\
\hline 111 & Barrenka - Streblus asper Lour. & $\begin{array}{l}\text { Wood hard, tough shoots used as tooth brush; } \\
\text { medicinal and used for making agricultural } \\
\text { implements; leaves used to polish wood. }\end{array}$ \\
\hline & Moringaceae & \\
\hline
\end{tabular}




\begin{tabular}{|c|c|c|}
\hline \multirow[t]{2}{*}{112} & $\begin{array}{l}\text { Adavi munaga - Moringa concanensis Nimmo } \\
\text { ex Dalzell \& A. Gibson }\end{array}$ & Stem bark as abortifacient. \\
\hline & Myrtaceae & \\
\hline \multirow[t]{2}{*}{113} & Jamu, Neredu - Syzygium cumini (L.) Skeels & $\begin{array}{l}\text { Fruits edible, wood moderately hard; ripe fruits eaten } \\
\text { for stomach ache. }\end{array}$ \\
\hline & Olacaceae & \\
\hline \multirow[t]{2}{*}{114} & Muriki malle - Olax scandens Roxb. & Fruits eaten, made sherbet. \\
\hline & Oleaceae & \\
\hline \multirow[t]{2}{*}{115} & Mokkam - Schrebera swietenoides Roxb. & Wood used as fuel. \\
\hline & Papilionaceae & \\
\hline 116 & Guruvinda - Abrus precatorius L. & Seeds used as ornaments; medicinal. \\
\hline 117 & Ulla teega - Atylosia scarabaeoides (L.) Benth. & Seeds as vegetable. \\
\hline 118 & Moduga - Butea monoserpma (Lam.) Taub. & $\begin{array}{l}\text { Flowers yield dye; host tree for lac insect; leaves } \\
\text { used to make meal plates. }\end{array}$ \\
\hline 119 & Teega moduga - Butea superba Roxb. & Flowers yield dye. \\
\hline 120 & Jitregi - Dalbergia latifolia Roxb. & $\begin{array}{l}\text { Fodder tree; seed oil used as antidote; wood hard, } \\
\text { durable. }\end{array}$ \\
\hline 121 & Patchari - Dalbergia paniculata Roxb. & Wood used for musical instruments. \\
\hline 122 & Nalla teega - Derris scandens (Roxb.) Benth. & Bark yields coarse rope fibre. \\
\hline 123 & $\begin{array}{l}\text { Seema kanuga - *Gliricidia sepium (Jacq.) } \\
\text { Kunth ex Walp. }\end{array}$ & Fodder and green manure. \\
\hline 124 & $\begin{array}{l}\text { Vandanamu - Ougeinia oojeinensis (Roxb.) } \\
\text { Hochr. }\end{array}$ & Bark used as fish poison. \\
\hline 125 & $\begin{array}{l}\text { Duldundi,Theta kokila - Mucuna pruriens (L.) } \\
\text { DC. }\end{array}$ & Vermifuse to cattle. \\
\hline 126 & Kanuga - Pongamia pinnata (L.) Pierre & Seed yields oil, biodiesel; shoots used as tooth brush. \\
\hline \multirow[t]{2}{*}{127} & Peddegi - Pterocarpus marsupium Roxb. & $\begin{array}{l}\text { Medicinal; gum as adhesive; wood agricultural } \\
\text { implements. }\end{array}$ \\
\hline & Rhamnaceae & \\
\hline 128 & Regu - *Ziziphus mauritiana Lam. & Fruits edible. \\
\hline 129 & Pariki-Ziziphus oenoplia (L.) Mill. & Fruits edible. \\
\hline \multirow[t]{2}{*}{130} & Gotte - Ziziphus xylopyrus (Retz.) Willd. & Excellent fodder for sheep, goats. \\
\hline & Rubiaceae & \\
\hline 131 & Baluchu - Psydrax dicoccos Gaertn. & Fodder. \\
\hline 132 & $\begin{array}{l}\text { Manga - Catunaregum spinosa (Thunb.) } \\
\text { Tirveng. }\end{array}$ & Fruit paste used as fish poison. \\
\hline 133 & Bikki - Gardenia gummifera L.f. & $\begin{array}{l}\text { Leaf buds and young shoots yield yellow resinous } \\
\text { gum, used in medicine; young fruits edible. }\end{array}$ \\
\hline 134 & Pedda bikki - Gardenia latifolia Aiton & $\begin{array}{l}\text { Shoot tips exude yellow gum resin; medicinal; fruits } \\
\text { edible. }\end{array}$ \\
\hline 135 & Chinna karinga - Gardenia resinifera Roth & Shoot tips exude yellow gum resin; medicinal. \\
\hline 136 & Bandari - Haldina cordifolia (Roxb.) Ridsdale & $\begin{array}{l}\text { Ethnomedicinal (antifertility, body pains), wood used } \\
\text { for agricultural implements. }\end{array}$ \\
\hline 137 & Korivi - Ixora arborea Roxb. & Branches used as torches. \\
\hline 138 & Puttapala, korivi - Ixora pavetta Andrews & Fodder tree. \\
\hline 139 & $\begin{array}{l}\text { Batta kanapa - Mitragyna parviflora (Roxb.) } \\
\text { Korth. }\end{array}$ & $\begin{array}{l}\text { Wood strong, used for furniture, agricultural } \\
\text { implements; bark used in fever; bark yields fibre, } \\
\text { fodder tree. }\end{array}$ \\
\hline 140 & $\begin{array}{l}\text { Thogara maddi - Morinda pubescens J.E. } \\
\text { Smith }\end{array}$ & Root yields yellow dye. \\
\hline \multirow[t]{2}{*}{141} & $\begin{array}{l}\text { Komi - Tarenna asiatica (L.) Kuntze ex K. } \\
\text { Schum. }\end{array}$ & Fruits vermicide. \\
\hline & Rutaceae & \\
\hline 142 & Maredu - Aegle marmelos (L.) Cor. & Sacred tree; bark and leaves medicinal; fruits edible. \\
\hline 143 & $\begin{array}{l}\text { Thorri velaga - Naringi crenulata (Roxb.) } \\
\text { Nicolson }\end{array}$ & Fodder tree. \\
\hline 144 & Velaga - Limonia acidissima L. & Pulp of the fruit edible, bark yields gum. \\
\hline
\end{tabular}




\begin{tabular}{|c|c|c|}
\hline 145 & $\begin{array}{l}\text { Adavi nimma - Atalantia monophylla (L.) } \\
\text { Corri. }\end{array}$ & Fruits pickled. \\
\hline \multirow{2}{*}{146} & Karivepa - *Murraya koenigii (L.) Spreng. & Flavouring agent. \\
\hline & Salvadoraceae & \\
\hline \multirow[t]{2}{*}{147} & Uppi - Azima tetracantha Lam. & Dried leaves fumigated as insect repellent. \\
\hline & Sapindaceae & \\
\hline 148 & Kunkudu - Sapindus emarginatus Vahl & $\begin{array}{l}\text { Fruit juice a detergent (soap, shampoo); used in } \\
\text { treatment of asthma. }\end{array}$ \\
\hline 149 & Pusuku - Schleichera oleosa (Lour.) Oken & $\begin{array}{l}\text { Suitable for lac rearing; fruits edible; flowers yield } \\
\text { dye; bark used in inflammation and ulcers; seed oil } \\
\text { used as hair oil. }\end{array}$ \\
\hline \multirow[t]{2}{*}{150} & Puli veli - Dodonaea viscosa (L.) Jacq. & $\begin{array}{l}\text { Wood used for, turning, tool handle, walking sticks, } \\
\text { etc. }\end{array}$ \\
\hline & Sapotaceae & \\
\hline 151 & Ippa - Madhuca indica J. Gmel. & $\begin{array}{l}\text { Fleshy corolla edible; flowers used for distillation of } \\
\text { spirit (ippa sara); seeds yield oil, used for skin } \\
\text { diseases. }\end{array}$ \\
\hline \multirow[t]{2}{*}{152} & $\begin{array}{l}\text { Manchi pala, Pala - Manilkara hexandra } \\
\text { (Roxb.) Dubard. }\end{array}$ & Fruits edible; shoots used in religious functions. \\
\hline & Scrophulariaceae & \\
\hline \multirow[t]{2}{*}{153} & Brahmi - Bacopa monnieri Wettst. & Medicinal, brain tonic. \\
\hline & Simaroubaceae & \\
\hline \multirow[t]{2}{*}{154} & Peda manu - **Ailanthus excelsa Roxb. & $\begin{array}{l}\text { Bark astringent, febrifuge and anthelmintic, yields } \\
\text { gum; leaves suitable for fodder. }\end{array}$ \\
\hline & Sterculiaceae & \\
\hline 155 & Nulthada-Helicteres isora L. & $\begin{array}{l}\text { Bark yields fibre; wood is used in charcoal; leaves } \\
\text { used as fodder. }\end{array}$ \\
\hline \multirow[t]{2}{*}{156} & Tapsi - Kavalama urens (Roxb.) Raf. & $\begin{array}{l}\text { Bark yields gum (used in pharmaceutical } \\
\text { preparations, tanneries, garbarti making, etc.) and } \\
\text { yields fibre; leaves fodder; seeds edible. }\end{array}$ \\
\hline & Tamaricaceae & \\
\hline \multirow[t]{2}{*}{157} & Jhau - Tamarix dioica Roxb. & Wood makes good fuel; basket making. \\
\hline & Tiliaceae & \\
\hline 158 & $\begin{array}{l}\text { Guvva tada, Pedda tada - Grewia abutilifolia } \\
\text { Vent. ex Juss. }\end{array}$ & Bark yields fibre. \\
\hline \multirow[t]{2}{*}{159} & Tada, boddi - Grewia tiliifolia Vahl & Bark yields fibre; tender leaves, fruits edible. \\
\hline & Ulmaceae & \\
\hline \multirow[t]{2}{*}{160} & $\begin{array}{l}\text { Nemali nara - Holoptelia integrifolia (Roxb.) } \\
\text { Planch. }\end{array}$ & Fodder tree; twigs used as fire wood. \\
\hline & Verbenaceae & \\
\hline 161 & Gummer teku - Gmelina arborea Roxb. & $\begin{array}{l}\text { Bark used as antidote for snakebite; wood used in } \\
\text { agricultural implements, furniture. }\end{array}$ \\
\hline 162 & Teku - Tectona grandis L. & $\begin{array}{l}\text { Seeds used in the treatment of bladder stones; } \\
\text { inflorescence for worship. }\end{array}$ \\
\hline \multirow[t]{2}{*}{163} & Vaili - Vitex negundo L. & $\begin{array}{l}\text { Leaves used in chronic fevers; hot water bath with } \\
\text { leaves relieves body pains. }\end{array}$ \\
\hline & Vitaceae & \\
\hline \multirow[t]{2}{*}{164} & Adavi draksha - Cissus vitiginea $\mathrm{L}$. & Fruits edible; ripe fruits eaten for stomach-ache. \\
\hline & Araceae & \\
\hline \multirow[t]{2}{*}{165} & $\begin{array}{l}\text { *Kanda - Amorphophallus paeoniifolius } \\
\text { (Dennst.) Nicoloson }\end{array}$ & Corms a vegetable. \\
\hline & Arecaceae & \\
\hline 166 & Thadi chettu - *Borassus flabellifer $\mathrm{L}$. & $\begin{array}{l}\text { Leaves used for thatching cottages, making hand } \\
\text { fans, umbrellas; fruits, seeds edible, toddy tapping. }\end{array}$ \\
\hline 167 & Eetha - Phoenix sylvestris Roxb. & $\begin{array}{l}\text { Leaves used for thatching and making mats, baskets, } \\
\text { bags, brooms; tree yields durable wood, used as } \\
\text { poles; toddy tapped from the tree, fruits edible. }\end{array}$ \\
\hline
\end{tabular}




\begin{tabular}{|c|c|c|}
\hline & Asparagaceae & \\
\hline \multirow[t]{2}{*}{168} & Pilli teegalu - Asparagus racemosus Willd. & Roots aphodisiac. \\
\hline & Dioscoriaceae & \\
\hline 169 & Bellam gadda - Dioscorea alata L. & Tubers edible. \\
\hline 170 & Chenna gadda - Dioscorea bulbifera L. & Aerial bulbs, tubers edible. \\
\hline \multirow[t]{2}{*}{171} & Govinda gadda - Dioscorea pentaphylla L. & Tubers edible. \\
\hline & Liliaceae & \\
\hline 172 & Kalabanda - *Aloe vera (L.) Burm.f. & $\begin{array}{l}\text { Leaves medicinal; used to cure piles and eye } \\
\text { infections. }\end{array}$ \\
\hline \multirow[t]{2}{*}{173} & Nabhi - Gloriosa superba L. & Tubers paste is used to cure leprosy. \\
\hline & Poaceae & \\
\hline 174 & Makka teega - Apluda mutica $\mathrm{L}$. & Fodder; thatching. \\
\hline 175 & $\begin{array}{l}\text { Mulla veduru, Veduru - Bambusa arundinacea } \\
\text { (Retz.) Roxb. }\end{array}$ & Making baskets, roofs and incense sticks. \\
\hline 176 & $\begin{array}{l}\text { Nimma gaddi - Cymbopogon flexuosus (Nees } \\
\text { ex Steud.) W.Watson }\end{array}$ & Oil medicinal. \\
\hline 177 & $\begin{array}{l}\text { Darba gaddi - Imperata cylindrica (L.) } \\
\text { Raeusch. }\end{array}$ & Thatching huts. \\
\hline 178 & $\begin{array}{l}\text { Konda cheepuru - Thysanolaena latifolia } \\
\text { (Roxb. ex Hornem.) Honda. }\end{array}$ & Brooms. \\
\hline 179 & Jammu gaddi - Typha angustifolia $\mathrm{L}$. & Roofing material; seeds for stuffing pillows. \\
\hline 180 & Jammu gaddi - Typha domingensis Pers. & Roofing material. \\
\hline \multirow[t]{2}{*}{181} & $\begin{array}{l}\text { Veduru - Dendrocalamus strictus (Roxb.) } \\
\text { Nees }\end{array}$ & Making baskets; household articles. \\
\hline & Smilacaceae & \\
\hline \multirow[t]{2}{*}{182} & Phirangi mokka - Smilax zeylanica L. & Roots aphrodisiac. \\
\hline & Zingiberaceae & \\
\hline 183 & $\begin{array}{l}\text { Kevu kanda - Cheilocostus speciosus } \\
\text { (J.Koenig) C. Specht }\end{array}$ & Tubers ethnomedicinal; chicken-pox; vegetable. \\
\hline
\end{tabular}

* Cultivated/Planted or running wild. ** Road side tree, not a forest element.

Table 2. Income generation from Beedi leaf collection in Adilabad district

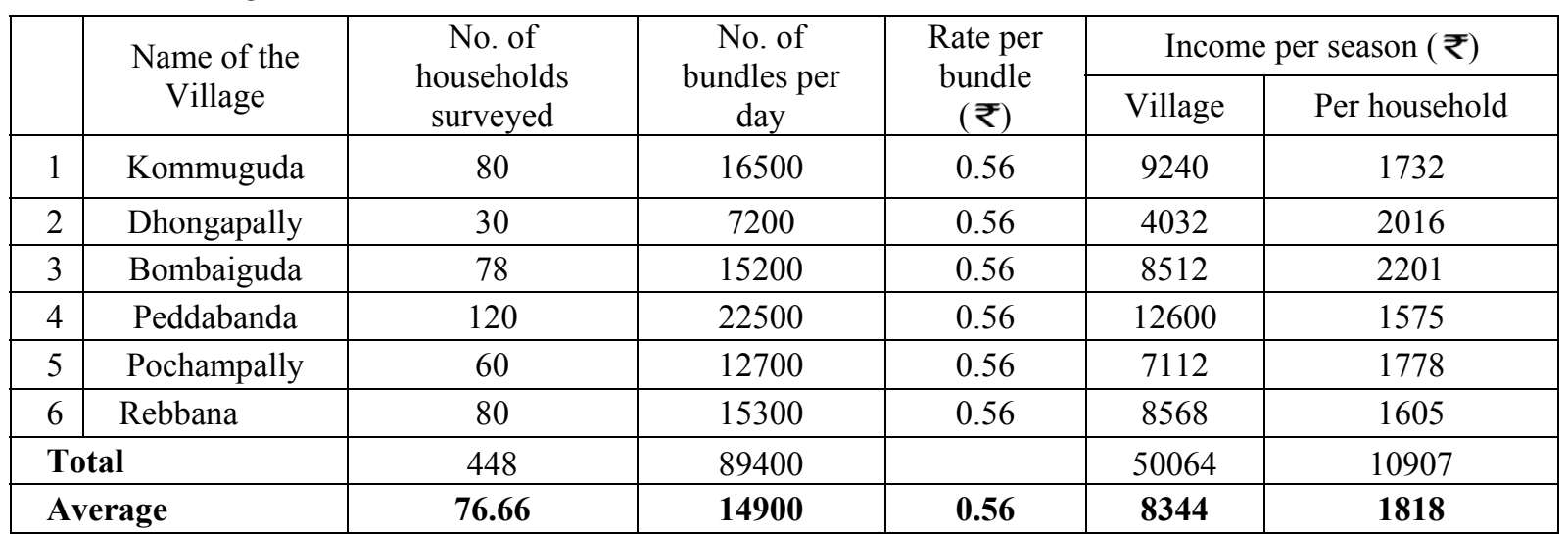

*Average household income in the study area $₹ 1818$ per season (15 days). 
Table 3. List of NTFPs available in Adilabad district under procurement policy with price index

\begin{tabular}{|c|c|c|c|c|c|}
\hline & Scientific Name & Vernacular Name & NTFP & Grade & Price (per kg) \\
\hline \multirow{3}{*}{1} & \multirow{3}{*}{ Kavalama urens } & \multirow{3}{*}{ Gum karaya } & \multirow{3}{*}{ Gum } & $\mathrm{I}$ & 140 \\
\hline & & & & II & 100 \\
\hline & & & & III & 75 \\
\hline \multirow{3}{*}{2} & \multirow{3}{*}{ Anogeissus latifolia } & \multirow{3}{*}{ Thiruman } & \multirow{3}{*}{ Gum } & I & 80 \\
\hline & & & & II & 60 \\
\hline & & & & III & 50 \\
\hline \multirow{3}{*}{3} & \multirow{3}{*}{$\begin{array}{l}\text { Cochlospermum } \\
\text { religiosum }\end{array}$} & \multirow{3}{*}{ Konda gogu } & \multirow{3}{*}{ Gum } & $\mathrm{I}$ & 120 \\
\hline & & & & II & 80 \\
\hline & & & & III & 60 \\
\hline 4 & Rauvolfia serpentina & Sarpagandhi roots & Root & & 60 \\
\hline 5 & Litsea glutinosa & Narra mamidi & Stem bark & & 23 \\
\hline 6 & Strychnos nux-vomica & Visha mushti & Seed & & 16 \\
\hline 7 & Strychnos potatorum & Chilla & Seed & & 9 \\
\hline 8 & Pongamia pinnata & Kanuga & Seed & & 10 \\
\hline 9 & Tamarindus indica & Chinta & Fruit with seed & & 15 \\
\hline 10 & Sapindus emarginatus & Kunkudu & Fruit & & 20 \\
\hline 11 & Madhuca indica & Iрpа риvvи, Iрpа поопе & Corolla, seed & & 11 \\
\hline 13 & Thysanolaena maxima & Cheepuru gaddi & Shoots & & 12 \\
\hline 14 & Terminalia chebula & Karakkaya & Fruit & & 03 \\
\hline 15 & Gardenia latifolia & Karengu gum & Gun-resin & & 12 \\
\hline 16 & Honey & Thene & Honey & & 80 \\
\hline 17 & Honey bees wax & Minam & Wax & & 100 \\
\hline
\end{tabular}

Source: Omkar (2011).

Table 4. Year-wise procurement of Gum Karaya in Adilabad district

\begin{tabular}{|c|c|c|c|}
\hline & Year & Quantity (Kg) & Value ( ₹ Lakhs) \\
\hline 1 & $2001-02$ & 660.45 & 49.48 \\
\hline 2 & $2002-03$ & 665.63 & 43.81 \\
\hline 3 & $2003-04$ & 679.25 & 49.86 \\
\hline 4 & $2004-05$ & 968.34 & 74.92 \\
\hline 5 & $2005-06$ & 714.36 & 55.46 \\
\hline 6 & $2006-07$ & 853.67 & 65.75 \\
\hline 7 & $2008-09$ & 192.79 & 14.92 \\
\cline { 2 - 4 } & Average & $\mathbf{5 9 0 . 6 4}$ & $\mathbf{5 0 . 6 0}$ \\
\hline
\end{tabular}

Source: GCC Limited, Utnoor. 